\title{
Peningkatan Proses Pembelajaran Tematik Terpadu Menggunakan Pendekatan Scientific di Sekolah Dasar
}

\author{
Vina Iasha \\ Universitas Negeri Jakarta \\ vina.iasha@gmail.com
}

\begin{abstract}
This study aims to describing the improvement of thematic learning process by using scientific approach in Grade 1 Elementary School of 04 Birugo Bukittinggi. This research used qualitative and quantitative approach. This research was classroom action research and had two cycles. The research subject was a teacher and 30 students of Grade 1 Elementary School of 04 Birugo Bukittinggi. The study's results shows the increasing in: Lesson plan of the first cycle is meeting $177,77 \%$ (good), meeting $288,89 \%$ (good), and the second cycle meeting 1 is $94,44 \%$ (very good), meeting $297,22 \%$ (very good). Teacher's activities in first cycle meeting 1 is 78,33\% (good), meeting 2 $86,67 \%$ (good), the second cycle meeting 1 is $93,33 \%$ (very good), meeting $296,67 \%$ (very good). Student's activities in first cycle meeting 1 is 78,33\% (good), meeting $286,67 \%$ (good), the second cycle meeting 1 is $93,33 \%$ (very good), meeting $296,67 \%$ (very good). Therefore, the scientifict method can increase the integrated thematic learning at elementary school.
\end{abstract}

Keywords : Integrated Thematic, Scientific Approach.

Abstrak : Penelitian ini bertujuan untuk mendeskripsikan peningkatan proses pembelajaran tematik terpadu menggunakan pendekatan scientific di kelas I SD Negeri 04 Birugo Kota Bukittinggi. Penelitian ini merupakan penelitian tindakan kelas dengan pendekatan kualitatif dan kuantitatif. Subjek penelitian siswa kelas I SD Negeri 04 Birugo Kota Bukittinggi sebanyak 30 orang. Hasil penelitian menunjukkan peningkatan pada RPP siklusI pertemuan $177,77 \%$ (baik), pertemuan 2 88,89\% (baik), siklus II pertemuan 1 94,44\% (amat baik), pertemuan 2 97,22 (amat baik). Pelaksanaan aktivitas guru siklus I pertemuan 1 $78,33 \%$ (baik), pertemuan $288,33 \%$ (baik), siklus II pertemuan 1 93,33\% (amat baik), pertemuan 2 96,67\% (amat baik). Aktivitas siswa siklus I pertemuan 176,67\% (baik), pertemuan 2 86,67\% (baik),, siklus II pertemuan 1 93,33\% (amat baik), pertemuan 2 96,67\% (amat baik). Dengan demikian pendekatan scientific dapat meningkatkan proses pembelajaran tematik terpadu di sekolah dasar.

AR-RIAYAH : Jurnal Pendidikan Dasar vol. 2, no. 1, 2018

STAIN Curup - Bengkulu| p ISSN 2580-362X; e ISSN 2580-3611

http://journal.staincurup.ac.id/index.php/JPD 
Kata Kunci : Tematik Terpadu; Pendekatan Scientific.

\section{PENDAHULUAN}

Kurikulum 2013 merupakan serentetan rangkaian penyempurnaan terhadap kurikulum yang telah dirintis tahun 2004 yang berbasis kompetensi lalu diteruskan dengan kurikulum 2006. Kurikulum2013 sudah mulai diterapkan sejak tahun ajaran 2013/2014. Ini sesuai dengan pendapat Mulyasa bahwa"Perubahan kurikulum bertujuan untuk melanjutkan pengembangan Kurikulum Tingkat Satuan Pendidikan yang telah dirintis pada tahun 2006 dengan mencakup kompetensi sikap, pengetahuan dan keterampilan secara terpadu".1 Perubahan yang akan diberlakukan diharapkan dapat memberikan perubahan pada model pembelajaran yang memberikan ruang gerak bagi siswa untuk berekspresi seluas-luasnya.

Pembelajaran tematik terpadu merupakan pembelajaran terpadu yang menggunakan tema untuk mengaitkan beberapa mata pelajaran sehingga dapat memberikan pengalaman bermakna kepada siswa. Menurut Poerwadarminta (dalam Majid) "Pembelajaran tematik adalah pembelajaran terpadu yang menggunakan tema untuk mengaitkan beberapa mata pelajaran sehingga memberikan pengalaman bermakna kepada murid".2 Proses pembelajaran tematik memungkinkan siswa untuk lebih aktif dalam menggali informasi, menemukan konsep serta prinsip-prinsip keilmuan secara holistik, bermakna, dan otentik.

Relevan dengan penelitian Varelas, $\mathrm{M}$ and Ford M, "The scientific approach allows teachers or curriculum developers to improve the learning process, namely by breaking the process down into steps or stages in detail which contain any instructions for the students to carry out any learning activities."3

Untuk dapat mengimplementasikan pembelajaran tematik terpadu dengan maksimal maka guru harus menggunakan pendekatan atau model-model yang efektif dan sesuai dengan pembelajaran. Salah satu pendekatan pembelajaran yang sesuai adalah pendekatan scientific.

Hal ini sesuai dengan pendapat Steven D. Schafersman dalam penelitiannya, "The scientific method is practiced within a context of scientific thinking, and

1 Mulyasa, E. Implementasi KTSP: Kemandirian Guru dan Kepala Sekolah. (Jakarta: Bumi Aksara, 2010), 23

2 Abdul Majid, Pembelajaran Tematik Terpadu. (Bandung: Rosdakarya, 2014), 80

3 Varelas, M and Ford M. The scientific method and scientific inquiry: Tensions in teaching and learning. (USA: Wiley Inter Science, 2009). 
scientific (and critical) thinking is based on three things: using empirical evidence (empiricism), practicing logical reasonsing (rationalism), and possessing a skeptical attitude (skepticism) about presumed knowledge that leads to self-questioning, bolding tentative conclusions, and being undogmatic (willingness to change one's beliefs)".4

Pendekatan scientific cocok digunakan pada pembelajaran tematik terpadu dalam rangka meningkatkan proses belajar siswa karena pendekatan ini menuntut keterlibatan aktif siswa dalam pembelajaran dan mengembangkan karakter siswa. 5 Siswa dituntut untuk memahami materi pelajaran karena kegiatan mengamati, menanya, mencoba/eksperimen, menalar dan mengkomunikasikan yang terdapat dalam pendekatan ini akan dipertanggungjawabkan pada hasil akhir pembelajaran.

Hal ini sesuai dengan penelitian Gauch, Hugh G. (2013) "The scientific method 'is often misrepresented as a fixed sequence of steps,' rather than being seen for what it truly is, 'a highly variable and creative process'”. Bahwa scientific memiliki langkah-langkah yangi merupakan prinsip umum yang harus dikuasai untuk meningkatkan produktivitas. Produktivitas disini diartikan tuntasnya tujuan pembelajaran.

Penelitian dilakukan berdasarkan observasi awal di kelas 1 SDN 04 Birugo kota Bukittinggi. Berdasarkan pengamatan peneliti, dari aspek perencanaan pembelajaran tematik terpadu, guru hanya menyalin apa yang ada pada buku guru, minimnya guru dalam mengembangkan model pembelajaran yang akan digunakan. Dari aspek pelaksanaan pembelajaran tematik terpadu, guru melaksanakan pembelajaran tematik terpadu masih terpisah-pisah. Guru cenderung lebih aktif dibandingkan dengan siswa. Media yang disajikan guru kurang menarik, sehingga pada proses pembelajaran. Pada pemberian contoh guru kurang mengaitkan dengan kehidupan nyata siswa.

Dampak yang lainnya tersebut juga menyebabkan siswa cenderung hanya mendengarkan penjelasan materi pembelajaran dari guru tanpa berani mengeluarkan ide-idenya dalam proses pembelajaran, serta proses pembelajaran yang berpusat kepada siswa (student centered) kurang terlihat. Siswa terlihat kurang tertarik, senang dan tertantang dalam mengikuti proses pembelajaran, karena

4 Steven D. Schafersman. http://www.geo.sunysb.edu/esp/files/ scientificmethod.html (diakses 04 Agustus 2017)

5 Sanjaya, Wina. Strategi Pembelajaran Berorientasi Standar Proses Pendidikan. (Jakarta: Kencana, 2011), 79 
media yang disajikan kurang menarik dan kurang menantang yang membuat siswa terlihat kurang aktif dan berfikir kritis. Dari aspek penilaian, guru cenderung melakukan penilaian di akhir proses pembelajaran saja, kurang tampak guru melakukan penilaian pada saat proses pembelajaran.

Proses pembelajaran di atas berdampak terhadap proses dan hasil belajar siswa pada pembelajaran tematik terpadu dimana hasil belajar siswa belum dapat tercapai secara maksimal sesuai dengan kriteria ketuntasan minimal (KKM) yang ditetapkan. Untuk mengatasi kondisi di atas, perlu diadakan pembaharuan pada strategi mengajar guru yang bersifat alamiah dan dekat dengan siswa. Salah satu alternatif tindakan yang dapat dilakukan adalah dengan menggunakan pendekatan scientific.

Menurut Majid, "Pendekatan scientific menekankan pada pentingnya kolaborasi dan kerja sama diantara peserta didik dalam menyelesaikan setiap permasalahan dalam pembelajaran".6 Oleh karena itu, guru sedapat mungkin menciptakan pembelajaran selain dengan tetap mengacu pada standar proses dimana pembelajarannya diciptakan suasana yang memuat eksplorasi, eloborasi dan konfirmasi, juga dengan mengedepankan kondisi peserta didik yang berperilaku ilmiah. 7

Berdasarkan uraian di atas, maka tujuan dari penelitian ini adalah untuk mendeskripsikan peningkatan proses pembelajaran tematik terpadu dengan menggunakan pendekatan scientific pada tema peristiwa alam di kelas I SDN 04 Birugo kota Bukittinggi.

\section{LANDASAN TEORI}

\section{a. Pengertian Pendekatan Scientific}

Pendekatan scientific adalah proses pembelajaran untuk memberikan pemahaman kepada peserta didik dalam mengenal, memahami berbagai materi menggunakan pendekatan ilmiah, dan informasi bisa berasal dari mana saja, kapan saja, tidak tergantung pada informasi searah guru".

Berdasarkan pendapat di atas, dapat disimpulkan bahwa pendekatan scientific merupakan suatu pendekatan dalam aktivitas pembelajarannya menggunakan pendekatan ilmiah yang mengarahkan siswa untuk aktif dalam mengenal dan memahami konsep melalui tahapan mengamati, bertanya, 
mencoba atau mengumpulkan informasi, menalar atau mengolah informasi, dan mengkomunikasikan.

\section{b. Karakteristik Pendekatan Scientific}

Pembelajaran dengan pendekatan scientific memiliki karakteristik sebagai berikut : Menurut Kurniasih, dkk (2014:33) karakterisitik pendekatan scientific adalah: (1) Berpusat pada siswa; (2) Melibatkan keterampilan proses sains dalam mengkonstruksi konsep, hukum atau prinsip; (3) Melibatkan proses-proses kognitif yang potensial dalam Mmerangsang perkembangan intelek, khususnya keterampilan berpikir tingkat tinggi siswa; (4) Dapat mengembangkan karakter siswa.

Berdasarkan pendapat di atas dapat disimpulkan bahwa karakterisitik pendekatan scientific adalah berpusat pada siswa. Melibatkan keterampilan berpikir tingkat tinggi siswa. melibatkan keterampilan proses sains, memelibatkan keterampilan proses pengetahuan yang potensial dan dapat mengembangkan karakter siswa.

\section{c. Keunggulan Pendekatan Scientific}

Pendekatan scientific memiliki keunggulan dalam proses pembelajarannya. Menurut Kemendikbud (2013:27) pendekatan scientific memiliki beberapa keunggulan, di antaranya:

(1) Meningkatkan kemampuan intelek, khususnya kemampuan berpikir tingkat tinggi siswa; (2) Membentuk kemampuan siswa dalam menyelesaikan suatu masalah secara sistematik; (3) Menciptakan kondisi pembelajaran di mana siswa merasa bahwa belajar itu merupakan suatu kebutuhan; (4) Diperolehnya hasil belajar yang tinggi; (5) Melatih siswa dalam mengkomunikasikan ide-ide, khususnya dalam menulis artikel ilmiah; (6) Mengembangkan karakter siswa.

Berdasarkan paparan diatas, keunggulan pendekatan scientific adalah dapat meningkatkan kemampuan intelek, khususnya kemampuan berpikir tingkat tinggi siswa sehingga siswa mampu dalam menyelesaikan suatu masalah secara sistematik, mengembangkan karakter, mengkomunikasikan ide-ide, menciptakan kondisi pembelajaran yang menarik dimana siswa merasa bahwa belajar itu merupakan suatu kebutuhan, serta siswa dapat memperoleh hasil belajar yang tinggi. 


\section{d. Langkah-langkah Pendekatan Scientific}

Dalam pengembangannya terhadap proses pembelajaran, pendekatan scientific memiliki beberapa langkah pelaksanaan yang dikemukakan berdasarkan sudut pandang yang berbeda.

Menurut Permendikbud Nomor 81 A Tahun 2013 lampiran IV8, proses pembelajaran terdiri atas lima pengalaman belajar pokok yaitu : (1) Mengamati; (2) Menanya; (3) Mengumpulkan informasi/ekperimen; (4) Mengasosiasikan/ mengolah informasi; dan (5) Mengkomunikasikan.

Sebagaimana yang dikemukakan oleh Hosnan9:

Langkah-langkah pendekatan ilmiah (scientific apprroach) dalam proses pembelajaran pada Kurikulum 2013 untuk semua jenjang dilaksanakan dengan menggunakan pendekatan ilmiah (saintifik) meliputi: menggali informasi melalui observing/ pengamatan, questioning/bertanya, experimenting/percobaan, kemudian mengolah data atau informasi, menyajikan data atau informasi, dilanjutkan dengan menganalisis, associating/ menalar, kemudian menyimpulkan, dan mencipta dan serta membentuk jaringan/ networking. Untuk mata pelajaran, materi, atau situasi tertentu, sangat mungkin pendekatan ilmiah ini tidak selalu tepat diaplikasikan secara prosedural. Pada kondisi seperti ini, tentu saja proses pembelajaran harus tetap menerapkan nilai-niai atau sifat-sifat ilmiah dan menghindari nilai-nilai atau sifat-sifat non-ilmiah.

Sejalan dengan itu, Kurniasih, dkk10 menyatakan bahwa pendekatan saintific dalam pembelajaran disajikan sebagai berikut:

1. Mengamati (observasi)

Metode mengamati mengutamakan kebermaknaan proses pembelajaran (meaningful learning). Metode ini memiliki keunggulan tertentu, seperti menyajikan media objek secara nyata, peserta didik senang dan tertantang, dan mudah pelaksanaannya. Metode mengamati sangat bermanfaat bagi pemenuhan rasa ingin tahu peserta didik. Sehingga proses pembelajaran memiliki kebermaknaan yang tinggi.

8 Permendikbud Nomor 81 A Tahun 2013 lampiran IV

9 Hosnan. 2014. Pendekatan Saintifik dan Kontekstual dalam Pembelajaran Abad 21. Bogor: Ghalia Indonesia., 37

10 Kurniasih, Imas \& Berlin Sani. 2014. Sukses Menimplementasikan Kurikulum 2013. Surabaya: Kata Pena., 38 
2. Menanya

Guru yang efektif mampu menginspirasi peserta didik untuk meningkatkan dan mengembangkan ranah sikap, keterampilan, dan pengetahuannya. Pada saat guru bertanya, pada saat itu pula dia membimbing atau memandu peserta didiknya, ketika itu pula dia mendorong asuhannya itu untuk menjadi penyimak dan pembelajar yang baik.

3. Mengumpulkan Informasi

Kegiatan "mengumpulkan informasi" merupakan tindak lanjut dari bertanya. Kegiatan ini dilakukan dengan menggali dan mengumpulkan informasi dari berbagai sumber melalui berbagai cara. Untuk peserta didik dapat membaca buku yang lebih banyak, memperhatikan fenomena atau objek yang lebih teliti, atau bahkan melakukan ekperimen. Dari kegiatan tersebut terkumpul sejumlah informasi. Dalam Permendikbud Nomor 81a Tahun 2013, aktivitas mengumpulkan informasi dilakukan melalui eksperimen, membaca sumber lain selain buku teks, mengamati objek/ kejadian, aktivitas wawancara dengan nara sumber dan sebagainya.

4. Mengasosiasikan/ Mengolah Informasi/ Menalar

Kegiatan "mengasosiasi/ mengolah informasi/ menalar" dalam kegiatan pembelajaran sebagaimana disampaikan dalam Permendikbud Nomor 81a Tahun 201311, adalah memproses informasi yang sudah dikumpulkan baik teratas dari hasi kegiatan mengamati dan kegiatan mengumpulkan/eksperimen maupun hasil dari kegiatan mengumpulkan/eksperimen maupun hasil dari kegiatan mengamati dan kegiatan mengumpulkan informasi.

5. Menarik kesimpulan

Kegiatan menyimpulkan dalam pembelajaran dengan pendekatan scientific merupakan kelanjutan dari kegiatan mengolah data atau informasi. Setelah menemukan keterkaitan antar informasi dan menemukan berbagai pola dari keterkaitan tersebut, selanjutnya secara bersama-sama dalam satu kesatuan kelompok, atau secara individual membuat kesimpulan.

\section{Ibid., 53}


6. Mengkomunikasikan

Pada pendekatan scientific guru diharapkan memberi kesempatan kepada peserta didik untuk mengkomunikasikan apa yang telah mereka pelajari. Kegiatan ini dapat dilakukan melalui menuliskan atau menceritakan apa yang ditemukan dalam kegiatan mencari informasi, mengasosiasikan dan menemukan pola. Hasil tersebut disampaikan di kelas dan dinilai oleh guru sebagai hasi belajar peserta didik atau kelompok peserta didik tersebut. Kegiatan "mengkomunikasikan" dalam kegiatan pembelajaran sebagaimana disampaikan dalam Permendikbud Nomor 81 A Tahun 2013 adalah menyampaikan hasil analisis secara lisan, tertulis, atau media lainnya.

\section{Pelaksanaan Pembelajaran Tematik Terpadu Menggunakan Pendekatan Scientific}

Pelaksanaan pendekatan scientific dalam pembelajaran tematik terpadu dapat membantu siswa dalam meningkatkan pemahaman tentang apa yang dipelajari sehingga siswa dapat menerapkannya dalam kondisi nyata. Untuk mencapai tujuan tersebut, langkah-langkah pendekatan scientific dalam pembelajaran tematik terpadu dengan tema benda, hewan, dan tanaman disekitarku dalam penulisan tindakan kelas ini mengarah kepada yang dikemukakan Permendikbud Nomor 81 A Tahun 2013 lampiran IV. Langkahlangkah pendekatan scientific terdiri dari lima langkah yaitu:

1. Mengamati

Pada langkah ini, kegiatan pembelajaran dimulai dengan mengamati gambar yang dipajang guru. Setelah itu guru bersama siswa melakukan tanya jawab tentang gambar yang diamati.

2. Menanya

Pada langkah ini siswa dibimbing untuk dapat mengajukan pertanyaanpertanyaan berdasarkan hasil pengamatan terhadap kegiatan mengamati hewan yang berukuran besar dan kecil. Siswa dilatih menggunakan pertanyaan dari guru, masih memerlukan bantuan guru untuk mengajukan pertanyaan sampai ke tingkat dimana siswa mampu mengajukan pertanyaan secara mandiri.

3. Menalar/Mengumpulkan informasi/eksperimen; 
Pada langkah ini, siswa dipancing dengan pertanyaan tentang hewan yang berukuran besar dan kecil yang ada di sekitarnya. Selain itu siswa juga berlatih membandingkan hewan berdasarkan ukuran dengan cara mengerjakan LKS.

\section{Mencoba}

Pada langkah ini siswa diajak bermain tebak nama binatang dalam kelompok. Kegiatan dilakukan dengan guru menunjukkan salah satu nama hewan pada perwakilan kelompok, kemudian perwakilan kelompok tersebut memberikan petunjuk berupa tempat tinggal binatang, ciri-ciri dan suara binatang.

5. Mengkomunikasikan

Pada langkah ini siswa diarahkan untuk mengkomunikasikan hasil diskusi yang ditemukan siswa secara kelompok. Siswa melaporkan dengan bahasa yang santun dan percaya diri.

\section{METODE PENELITIAN}

Penelitian ini menggunakan jenis Penelitian Tindakan Kelas (PTK) dengan menggunakan analisis data kualitatif dan kuantitatif dengan subjek penelitian guru dan 30 orang siswa kelas I SDN 04 Birugo Kota Bukittinggi pada semester II Tahun Ajaran 2016/2017. (Data Primer SDN 04 Birugo Kota Bukittinggi, 2017). Penelitian ini menggunakan alur penelitian model Kemmis \& Mc Taggart, dkk (dalam Kunandar, 2008: 70-75): "Secara garis besar terdapat empat tahapan yang dilalui, yaitu (1) perencanaan, (2) pelaksanaan, (3) pengamatan, dan (4) refleksi ".12

Teknik pengumpulan data dilakukan secara observasi dan tes. Observasi dilakukan untuk mengamati keadaan dan suasana pembelajaran tematik terpadu dengan menggunakan pendekatan scientific yang digunakan untuk melihat aktivitas guru, aktivitas siswa dan kegiatan pembelajaran dengan berpedoman pada lembar observasi yang telah disediakan. Tes digunakan untuk memperkuat data observasi yang terjadi dalam kelas terutama pada butir penguasaan materi pembelajaran dari unsur siswa. 13 


\section{HASIL PENELITIAN dan PEMBAHASAN}

\section{Siklus I ( Pertemuan I dan Pertemuan II)}

\section{Perencanaan}

Materi pembelajaran dilaksanakan pada siklus I pertemuan I ini adalah menjelaskan pengelompokkan ciri benda hidup dan tak hidup, menghafal teks lagu "bintang kecil" dan menyanyikan lagu bintang kecil dengan gerakannya. Penyusunan perencanaan tindakan dilakukan berdasarkan kurikulum 2013 dan dituangkan dalam seperangkat Rencana Pelaksanaan Pembelajaran (RPP) secara kolaboratif antara peneliti dan guru kelas I.

\section{Pelaksanaan}

Siklus I pertemuan I ini dilaksanakan pada hari Selasa tanggal 08 Maret 2017 selama 1 hari pembelajaran dari pukul 08.00-11.30 WIB. Pelaksanaan dilaksanakan berdasarkan RPP yang disusun, pembelajaran tematik terpadu pada penelitian melalui tiga langkah, yaitu kegiatan pendahuluan, kegiatan inti, dan kegiatan penutup dengan menggunakan pendekatan scientific menurut Permendikbud Nomor 81 A Tahun 2013, yaitu : (1) mengamati; (2) menanya; (3) mengumpulkan infomasi/eksperimen; (4) mengasosiasikan/mengolah informasi; (5) mengkomunikasikan.14

\section{Pengamatan}

Pengamatan dilakukan setiap siklus, dimana hasil yang diperoleh yaitu berdasarkan hasil observasi terhadap RPP, yaitudengan skor 28 dari skor maksimal 36, persentase 77,77\% dengan kategori baik (B) dan pertemuan II diperoleh jumlah skor 32 dari skor maksimal 36, persentase 88,89\% dengan kategori baik (B). Berdasarkan hasil observasi yang dilakukan terhadap aktivitas guru, dalam pembelajaran siklus I pertemuan I jumlah skor yang diperoleh 47 dari skor maksimal 60 dengan persentase 78,33\% dengan kategori baik (B) dan pertemuan II jumlah skor yang diperoleh 53 dari skor maksimal 60 dengan persentase 88,33\% dengan kategori baik (B). Sedangkan siswa, skor yang diperoleh 47 dari skor maksimal 60 dengan persentase 78,33\% dengan kategori baik (B) dan pada pertemuan II skor yang diperoleh 53 dari skor maksimal 60 dengan persentase $88,33 \%$ dengan kategori cukup (B).

14 Permendikbud Nomor 81 A Tahun 2013 Lampiran IV tentang proses pembelajaran pendekatan scientific 
Berdasarkan penilaian proses dan hasil belajar siswa pada pertemuan I di siklus I dari aspek sikap, pengetahuan, dan keterampilan diperoleh gambaran bahwa dari 30 orang siswa hanya 16 orang siswa mampu mencapai standar ketuntasan belajar minimal dan 14 orang siswa belum mampu mencapai standar ketuntasan belajar minimal. Dari proses dan hasil belajar yang diperoleh dapat diuraikan: (1) Aspek sikap, keberhasilan siswa dari aspek sikap dilihat selama proses pembelajaran berlangsung selama siklus I pertemuan I adalah 58,61 dengan konversi nilai 2,34 (C); (2) Aspek pengetahuan, keberhasilan siswa dari aspek pengetahuan pada pertemuan ini adalah adalah 63,7dengan konversi nilai 2,55 (B-); (3) Aspek keterampilan, keberhasilan siswa dari aspek keterampilan pada pertemuan ini adalah 71,25 dengan konversi nilai 2,85(B-). Dengan demikian rekapitulasi nilai dari ketiga aspek tersebut adalah 64,51dengan konversi nilai 2,33 (B-).

Sedangkan, penilaian proses dan hasil belajar siswa di pertemuan II pada siklus I dari aspek sikap, pengetahuan, dan keterampilan diperoleh gambaran bahwa dari 30 orang siswa hanya 20 orang siswa mampu mencapai standar ketuntasan belajar minimal. Dari proses dan hasil belajar yang diperoleh dapat diuraikan: (1) Aspek sikap, keberhasilan siswa dari aspek sikap dilihat selama proses pembelajaran berlangsung selama siklus I pertemuan II adalah 65,42 dengan konversi nilai 2,62(B); (2) Aspek pengetahuan, keberhasilan siswa dari aspek pengetahuan pada pertemuan iniadalah 81,33 dengan konversi nilai 3,25(B+); (3) Aspek keterampilan, keberhasilan siswa dari aspek keterampilan pada pertemuan ini77,71dengan konversi 3,11 nilai (B). Dengan demikian rekapitulasi nilai dari ketiga aspek tersebut adalah 74,82 dengan konversi nilai 2,99 (B).

\section{Refleksi}

Dari refleksi pada siklus I pertemuan I dan pertemuan II, disimpulkan bahwa tujuan pembelajaran yang diharapkan pada siklus I pertemuan I dan pertemuan II belum tercapai dengan baik. Dengan demikian, peningkatan proses pembelajaran tematik terpadu dengan menggunakan pendekatan scientific peneliti lanjutkan pada siklus II dengan memperhatikan kendala dan kelemahan yang ditemui pada siklus I diperbaiki pada siklus I pertemuan II.15

15 Ibid., 10 


\section{Siklus II (Pertemuan I dan Pertemuan II)}

\section{Perencanaan}

Materi pembelajaran yang dilaksanakan pada siklus II pertemuan I adalah tempat hidup hewan. Penyusunan perencanaan tindakan dilakukan berdasarkan kurikulum 2013 dan dituangkan dalam seperangkat Rencana Pelaksanaan Pembelajaran (RPP) secara kolaboratif antara peneliti dan guru kelas I.

\section{Pelaksanaan}

Siklus II pertemuan I ini dilaksanakan pada hari Selasa tanggal 22 Maret 2017 selama 1 hari pembelajaran dari pukul 08.00-11.30 WIB. Berdasarkan RPP yang disusun sebelumnya, pembelajaran tematik terpadu pada penelitian ini melalui tiga langkah, yaitu kegiatan pendahuluan, kegiatan inti, dan kegiatan penutup dengan menggunakan pendekatan scientific sesuai dengan langkah menurut Permendikbud Nomor 81 A Tahun 2013.

\section{Pengamatan}

Berdasarkan hasil observasi terhadap RPP, pembelajaran siklus II pertemuan I diperoleh jumlah skor 34 dari skor maksimal 36 dengan persentase 94,44\% dengan kategori amat baik (AB). Dan pada pertemuan II diperoleh jumlah skor 35 dari skor maksimal 36 dengan persentase 97,22\% dengan kategori amat baik (AB).

Berdasarkan hasil observasi yang dilakukan terhadap aktivitas guru, dalam pembelajaran siklus II pertemuan I jumlah skor yang diperoleh 56 dari skor maksimal 60 dengan persentase 93,33\% dengan kategori baik (AB). Sedangkan siswa, skor yang diperoleh 56 dari skor maksimal 60 dengan persentase 93,33\% dengan kategori baik (AB) dan pertemuan II diperoleh jumlah skor 35 dari skor maksimal 36 dengan persentase 97,22\% dengan kategori amat baik (AB). Berdasarkan hasil observasi yang dilakukan terhadap aktivitas guru, dalam pembelajaran siklus II pertemuan II jumlah skor yang diperoleh 58 dari skor maksimal 60 dengan persentase 96,67\% dengan kategori amat baik (AB). Sedangkan siswa, skor yang diperoleh 58 dari skor maksimal 60 dengan persentase 96, 67\% dengan kategori amat baik (AB).

Penilaian terhadap siswa dengan menggunakan pendekatan scientific dilihat selama proses pembelajaran yang berlangsung.16 Berdasarkan penilaian proses dan hasil belajar siswa dari aspek sikap, pengetahuan, dan keterampilan 
diperoleh gambaran bahwa dari 39 orang siswa, 1 orang siswa belum mampu mencapai standar ketuntasan belajar minimal. Dari proses dan hasil belajar yang diperoleh dapat diuraikan: (1) Aspek sikap, keberhasilan siswa dari aspek sikap dilihat selama proses pembelajaran berlangsung selama siklus II pertemuan I dengan adalah 87,5 dengan konversi 3,5 (AB) dan pertemuan II dengan adalah 91,25 dengan konversi nilai 3,65 (AB); (2) Aspek pengetahuan, keberhasilan siswa dari aspek pengetahuan pada pertemuan ini adalah 83,7dengan konversi 3,335 (A-) dan pada pertemuan II 91,74 dengan konversi nilai 3,67 (A) ; (3) Aspek keterampilan, keberhasilan siswa dari aspek keterampilan pada pertemuan iniadalah 92,22 dengan konversi 3,69 (A-). Dengan demikian rekapitulasi nilai dari ke 3 aspek tersebut adalah 93,36 dengan konversi nilai 3,73 (AB) dan 93,36 dengan konversi nilai 3,73 (A).

\section{PEMBAHASAN}

\section{Siklus I Pertemuan I}

\section{Rencana Pelaksanaan Pembelajaran}

Pada siklus I pertemuan I, sebelum melaksanakan proses pembelajaran peneliti terlebih dahulu merancang rencana pelaksanaan pembelajaran (RPP). Hasil dari penilaian terhadap rencana pelaksanaan pembelajaran (RPP) yang disusun oleh guru pada siklus I pertemuan I termasuk dalam baik, namun masih ada beberapa deskriptor yang belum muncul atau terlaksana. Penelitian pada siklus I pertemuan I dilaksanakan sesuai dengan langkah-langkah pendekatan scientific yang terdiri dari: (1) mengamati; (2) menanya; (3) mengumpulkan infomasi/eksperimen;(4) mengasosiasikan/mengolah informasi; mengkomunikasikan.

Deskriptor yang tidak muncul tersebut seperti, ketidaksesuaian rumusan indikator dengan perkembangan peserta didik, ketidaksesuaian tujuan pembelajaran dengan rumus ABCD, ketidaksesuaian tujuan pembelajaran dengan karakteristik yang diinginkan. Untuk pertemuan selanjutnya, guru sebaiknya memperbaiki kekurangan-kekurangan tersebut untuk meningkatkan esensi RPP di siklus berikutnya sehingga pelaksanaan pembelajaran yang mengacu pada perencanaan hasilnya pun juga maksimal. Hasil penilaian RPP pada siklus I pertemuan I diperoleh persentase nilai rata-rata 77,77\% (B), dimana termasuk ke dalam kriteria baik. Kekurangan pada siklus I pertemuan I ditersebut diperbaiki pada siklus berikutnya untuk meningkatkan kualitas pelaksanaan pembelajaran, proses dan hasil belajar siswa. 


\section{Pelaksanaan Pembelajaran}

Berdasarkan perencanaan yang disusun, pelaksanaan pembelajaran yang dilaksanakan sudah sesuai dengan apa yang telah direncanakan dan mengikuti langkah-langkah dalam pendekatan scientific, namun masih belum sepenuhnya terlaksana secara maksimal. Deskriptor yang tidak muncul yaitu tidak mengkondisikan kelas, tidak memberikan appersepsi, tidak menyampaikan tujuan pembelajaran, tidak mengamati cuaca yang terjadi sedang belajar, tidak bertanya jawab tentang musim, siswa lain tidak memberi tanggapan terhadap pertanyaan temannya, siswa lainnya tidak menyimak sambil membaca dalam hati, siswa tidak menyebutkan kembali benda-benda yang biasa digunakan saat musim kemarau dan tidak memperlihatkan hasil pola baju yang dibuat, tidakbertanya jawab tentang materi yang telah dipelajari, dan tidakmenyampaikan kesimpulan.

Berdasarkan hasil pengamatan, dapat disimpulkan bahwa pembelajaran tematik terpadu menggunakan pendekatan scientific belum terlaksana dengan maksimal. Dari hasil pengamatan penelitian siklus I pertemuan I dapat dilihat hasil penilaian aktivitas guru adalah $68 \%(\mathrm{~K})$ dengan kriteria kurang. Sedangkan hasil penilaian aktivitas siswa pada siklus I pertemuan I adalah 68\% (K) dengan kriteria kurang. Kekurangan pada pelaksanaan siklus I pertemuan I ini harus diperbaiki pada siklus berikutnya.17

\section{Penilaian terhadap Siswa dalam Proses Pembelajaran Tematik Terpadu dengan Menggunakan Pendekatan Scientific pada Siklus I Pertemuan I}

Pencapaian proses dan hasil belajar siswa sebelum dan sesudah melaksanakan pembelajaran tematik terpadu dengan menggunakan pendekatan scientific pada siklus I pertemuan I dapat dikatakan cukup, namun hanya mencapai batas KKM, belum melebihi dari batas KKM. Penilaian yang dilakukan guru terdiri 3 aspek yaitu aspek sikap, aspek pengetahuan, dan aspek sikap.

Rekapitulasi nilai rata-rata siklus I pertemuan I dari aspek sikap, pengetahuan dan keterampilan adalah 66,89 dengan konversi 2,33 (C). Adapun persentase ketuntasan siswa dari ketiga aspek tersebut adalah 59\%. Untuk itu perlu diadakan tindakan dan dilanjutkan pada siklus I pertemuan II. 


\section{Siklus I Pertemuan II}

\section{Rencana Pelaksanaan Pembelajaran}

Rencana pelaksanaan pembelajaran (RPP) pada siklus I pertemuan II mencapai keberhasilan dengan baik, tetapi masih ada deskriptor yang belum muncul. Penelitian pada siklus I pertemuan II dilaksanakan sesuai dengan langkah-langkah pendekatan scientific.

Beberapa deskriptor yang tidak muncul yaitu perumusan tujuan pembelajaran belum sesuai dengan indikator, pemilihan materi ajar belum sesuai dengan alokasi waktu,scenario pembelajaran belum sesuai dengan penyajian sistematika materi dan belum sesuai dengan alokasi waktu. Untuk pertemuan selanjutnya, guru sebaiknya memperbaiki kekurangan-kekurangan tersebut untuk meningkatkan esensi RPP di siklus berikutnya sehingga pelaksanaan pembelajaran yang mengacu pada perencanaan hasilnya pun juga maksimal. Hasil penilaian RPP pada siklus I pertemuan II ini diperoleh persentase nilai rata-rata $86 \%$ (B), dimana termasuk ke dalam kriteria baik. Berdasarkan kumulasi dari persentase pertemuan I dan pertemuan II pada siklus I maka diperoleh 83,5\% (B) dengan kriteria baik.

Kekurangan-kekurangan dalam perencanaan pelaksanaan pembelajaran pada siklus I pertemuan II berdampak pada proses pelaksanaan dan hasil pembelajaran. Pembelajaran yang kurang sesuai dengan karakteristik siswa mengakibatkan pembelajaran tematik terpadu kurang bermakna bagi siswa. Kekurangan ini diperbaiki pada perencanaan pelaksanaan pembelajaran siklus II pertemuan I untuk meningkatkan proses pelaksanaan dan hasil pembelajaran.

\section{Pelaksanaan Pembelajaran}

Berdasarkan perencanaan yang disusun, pelaksanaan pembelajaran dilaksanakan sudah sesuai dengan apa yang telah direncanakan dan mengikuti langkah-langkah pendekatan scientific, namun masih belum sepenuhnya terlaksana secara maksimal. Pelaksanaan pembelajaran tematik terpadu menggunakan pendekatan scientific dilaksanakan selama 5 × 35 menit. Deskriptor yang tidak muncul yaitu tidak tanya jawab tentang materi yang akan dibahas, tidak mengamati tentang musim yang terjadi pada beberapa hari sebelumnya, tidak memberikan pertanyaan tentang musim dan jenis musim di Indonesia, siswa tidak diarahkan untuk membuat tebak-tebakan, siswa tidak 
memperlihatkan hasil karya, dan tidak bertanya jawab tentang materi yang telah dipelajari.

Berdasarkan hasil pengamatan dapat disimpulkan bahwa pembelajaran tematik terpadu dengan menggunakan pendekatan scientific belum terlaksana secara maksimal. Dari hasil pengamatan penelitian siklus I pertemuan II dapat dilihat hasil penilaian aktivitas guru adalah 78\% (C) dengan kriteria cukup. Sedangkan hasil penilaian aktivitas siswa pada siklus I pertemuan II adalah $78 \%$ (C) dengan kriteria cukup. Berdasarkan kumulasi dari persentase pertemuan I dan pertemuan II pada siklus I maka diperoleh $72 \%$ (C) dengan kriteria cukup. Untuk pelaksanaan yang lebih maksimal, maka dilakukan tindakan pada siklus II pertemuan I agar persentase proses pembelajaran lebih meningkat.

\section{Penilaian terhadap Siswa dalam Proses Pembelajaran Tematik Terpadu dengan Menggunakan Pendekatan Scientific pada Siklus I Pertemuan II}

Pencapaian proses dan hasil belajar siswa sesudah melaksanakan pembelajaran tematik terpadu dengan menggunakan pendekatan scientific pada siklus I pertemuan II dapat dikatakan sudah baik dibandingkan daripada siklus sebelumnya. Penilaian yang dilakukan guru meliputi tiga aspek yaitu aspek sikap, pengetahuan, dan keterampilan. Rekapitulasi nilai rata-rata dari aspek sikap, pengetahuan dan keterampilan siklus I pertemuan II adalah 73,14 dengan konversi nilai 3 (B). Adapun persentase ketuntasan siswa dari ketiga aspek tersebut adalah 68\%. Berdasarkan kumulasi dari nilai pertemuan I dan pertemuan II pada siklus I maka diperoleh 70,01 dengan dengan konversi nilai 2,66 (B-).

Berdasarkan pendapat di atas, maka dapat disimpulkan bahwa dapat dijadikan dasar perbaikan perkembangan belajar siswa. Hasil yang diperoleh siswa dalam pembelajaran dapat digunakan guru sebagai pedoman dalam menganalisis perkembangan belajar siswa dalam pembelajaran tematik terpadu. Berdasarkan hasil pengamatan yang diperoleh pada siklus I pertemuan II, maka perlu dilaksanakan tindakan pada siklus II pertemuan I.

\section{Siklus II Pertemuan I}

\section{Rencana Pelaksanaan Pembelajaran}

Rencana pelaksanaan pembelajaran (RPP) pada siklus II pertemuan I mencapai keberhasilan dengan baik, tetapi masih ada deskriptor yang belum muncul. Penelitian pada siklus II pertemuan I dilaksanakan sesuai dengan langkah-langkah pendekatan scientific. Beberapa deskriptor yang tidak muncul 
yaitu perumusan tujuan pembelajaran belum sesuai perumusan tujuan pembelajaran yang tidak menimbulkan penafsiran ganda, penyajian belum sesuai dengan sistematika materi, rancangan penilaian belum sesuai dengan aspek pengetahuan. Untuk pertemuan selanjutnya, guru sebaiknya memperbaiki kekurangan-kekurangan tersebut untuk meningkatkan esensi RPP di siklus berikutnya sehingga pelaksanaan pembelajaran yang mengacu pada perencanaan hasilnya pun juga maksimal.

Hasil penilaian RPP pada siklus II pertemuan I ini diperoleh persentase nilai rata-rata $91 \%$ (AB), dimana termasuk ke dalam kriteria amat baik.Kekurangan-kekurangan dalam perencanaan pelaksanaan pembelajaran pada siklus II pertemuan I berdampak pada proses pelaksanaan dan hasil pembelajaran. Pembelajaran yang kurang sesuai dengan karakteristik siswa mengakibatkan pembelajaran tematik terpadu kurang bermakna bagi siswa. Kekurangan ini diperbaiki pada perencanaan pelaksanaan pembelajaran siklus II pertemuan II untuk meningkatkan proses pelaksanaan dan hasil pembelajaran.

\section{Pelaksanaan Pembelajaran}

Berdasarkan perencanaan yang disusun, pelaksanaan pembelajaran dilaksanakan sudah sesuai dengan apa yang telah direncanakan dan mengikuti langkah-langkah pendekatanscientific, namun masih belum sepenuhnya terlaksana secara maksimal. Pelaksanaan pembelajaran tematik terpadu menggunakan pendekatan scientific dilaksanakan selama 5 x 35 menit. Deskriptor yang tidak muncul yaitu tidak memberikan pertanyaan apa yang terjadi jika Tuhan hanya menciptakan satu musim saja, siswa tidak menyebutkan apa saja perbedaan gambar 1 dan 2, siswa tidak menuliskan hasil pengamatannya dan mendiskusikannya, tidak mengulas manfaat musim bagi kehidupan manusia, dan siswa lain tidak mengomentari gambar yang dipresentasikan.

Berdasarkan hasil pengamatan dapat disimpulkan bahwa pembelajaran tematik terpadu dengan menggunakan pendekatan scientific belum terlaksana secara maksimal. Dari hasil pengamatan penelitian siklus II pertemuan I dapat dilihat hasil penilaian aktivitas guru adalah $87 \%$ (B) dengan kriteria baik. Sedangkan hasil penilaian aktivitas siswa pada siklus II pertemuan I adalah 87\% (B) dengan kriteria baik. Untuk pelaksanaan yang lebih maksimal, maka dilakukan tindakan pada siklus II pertemuan II agar persentase proses pembelajaran lebih meningkat. 


\section{Penilaian terhadap Siswa dalam Proses Pembelajaran Tematik Terpadu dengan Menggunakan Pendekatan Scientific pada Siklus II Pertemuan I}

Pencapaian proses dan hasil belajar siswa sesudah melaksanakan pembelajaran tematik terpadu dengan menggunakan pendekatan scientific pada siklus I pertemuan II dapat dikatakan sudah baik dibandingkan daripada siklus sebelumnya. Penilaian yang dilakukan guru meliputi tiga aspek yaitu aspek sikap, pengetahuan, dan keterampilan. Rekapitulasi nilai rata-rata dari aspek sikap, pengetahuan dan keterampilan siklus I pertemuan II adalah 75,91 dengan konversi nilai 3,33 $(\mathrm{B}+)$. Adapun persentase ketuntasan siswa dari ketiga aspek tersebut adalah $89 \%$.

Berdasarkan pendapat di atas, maka dapat disimpulkan bahwa dapat dijadikan dasar perbaikan perkembangan belajar siswa. Hasil yang diperoleh siswa dalam pembelajaran dapat digunakan guru sebagai pedoman dalam menganalisis perkembangan belajar siswa dalam pembelajaran tematik terpadu. Berdasarkan hasil pengamatan yang diperoleh pada siklus II pertemuan I, maka perlu dilaksanakan tindakan pada siklus II pertemuan II.

\section{Siklus II pertemuan II}

\section{Rencana Pelaksanaan Pembelajaran}

Rencana pelaksanaan pembelajaran (RPP) pada siklus II pertemuan II mencapai keberhasilan dengan sangat baik, hanya beberapa deskriptor yang belum muncul. Penelitian pada siklus II pertemuan II dilaksanakan sesuai dengan langkah-langkah pendekatan scientific.

Beberapa deskriptor yang tidak muncul yaitu scenario pemilihan media belajar belum sesuai dengan karakteristik siswa. Hasil penilaian RPP pada siklus II pertemuan II diperoleh persentase nilai rata-rata 97\% (AB), dimana termasuk ke dalam kriteria amat baik. Berdasarkan kumulasi dari persentase pertemuan I dan pertemuan II pada siklus II maka diperoleh 94\% (AB) dengan kriteria amat baik. Berdasarkan hasil penilaian RPP, perbaikan pelaksanaan pembelajaran dari siklus-siklus sebelumnya meningkatkan proses pelaksanaan dan hasil pembelajaran pada siklus II pertemuan II.

\section{Pelaksanaan Pembelajaran}

Berdasarkan perencanaan yang disusun, pelaksanaan pembelajaran dilaksanakan sudah sesuai dengan apa yang telah direncanakan dan mengikuti langkah-langkah pendekatan scientific, namun masih belum sepenuhnya terlaksana secara maksimal. Pelaksanaan pembelajaran tematik terpadu menggunakan pendekatan scientific dilaksanakan selama 5 x 35 menit. Deskriptor yang tidak muncul yaitu tidak menyampaikan kepada siswa bahwa air hujan yang turun ke sungai, akan mengalir kembali ke laut, dan siswa tidak berdo'a untuk mengakhiri kegiatan pembelajaran. 
Berdasarkan hasil pengamatan dapat disimpulkan bahwa pembelajaran tematik terpadu dengan menggunakan pendekatan scientific sudah terlaksana dengan maksimal. Dari hasil pengamatan penelitian siklus II pertemuan II dapat dilihat hasil penilaian aktivitas guru adalah 93\% (AB) dengan kriteria amat baik. Sedangkan hasil penilaian aktivitas siswa pada siklus IIpertemuan II adalah 93\% (AB) dengan kriteria amat baik. Berdasarkan akumulasi dari persentase pertemuan I dan pertemuan II pada siklus II maka diperoleh 90\% (B) dengan kriteria baik. Dari hasil tersebut, proeses pembelajaran sudah dapat dikatakan berhasil. Oleh karena itu, penelitian dicukupkan sampai siklus II pertemuan II.

\section{Penilaian terhadap Siswa dalam Proses Pembelajaran Tematik Terpadu dengan Menggunakan Pendekatan Scientific pada Siklus II Pertemuan II}

Pencapaian proses dan hasil belajar siswa sebelum dan sesudah melaksanakan pembelajaran tematik terpadu dengan menggunakan pendekatan scientific pada siklus II pertemuan II dapat dikatakan amat baik dibandingkan sebelum dilakukan tindakan. Adapun penilaian yang dilakukan guru meliputi tiga aspek yaitu aspek sikap, pengetahuan, dan keterampilan.Rekapitulasi nilai rata-rata dari aspek sikap, pengetahuan dan keterampilan siklus II pertemuan II adalah 83,27 dengan konversi nilai 3,66 (A-). Adapun persentase ketuntasan dari ketiga aspek tersebut adalah 94\%. Berdasarkan akumulasi dari nilai pertemuan I dan pertemuan II pada siklus II maka diperoleh 79,59 dengan dengan konversi nilai $3,33(\mathrm{~B}+)$.

Berdasarkan pendapat di atas, maka dapat disimpulkan bahwa dengan menggunakan pendekatan scientific dapat membuat siswa tertarik dan termotivasi untuk belajar. Hal ini berarti menggunakan pendekatan scientific dapat digunakan oleh guru sebagai suatu pendekatan yang baik untuk digunakan dalam proses pembelajaran tematik terpadu sehingga dapat mencapai tujuan yang diinginkan serta dapat menciptakan suasana belajar yang menyenangkan dan bermakna bagi siswa.

\section{SIMPULAN}

Berdasarkan hasil penelitian yang diperoleh, maka disarankan agar : 1) Diharapkan kepada guru untuk dapat menggunakan pendekatan scientific sebagai salah satu alternatif dalam merancang RPP sesuai kurikulum 2013 dengan memilih model pembelajaran yang disesuaikan dengan materi pembelajaran tematik terpadu yang dapat menambah wawasan guru dalam bidang keilmuan. 2) Diharapkan kepada guru, agar dapat melaksanakan pembelajaran tematik terpadu dengan menggunakan pendekatan scientific yang sesuai dengan langkahlangkah pendekatan scientific. 3) Diharapkan kepada guru agar dapat meningkatkan proses dan hasil pembelajaran tematik terpadu dengan menggunakan pendekatan scientific. 
36 | AR-RIAYAH : Jurnal Pendidikan Dasar vol. 2, no. 1, 2018

\section{DAFTAR PUSTAKA}

Ahmadi, Iif Khoiru dan Sofan Amri. 2014. Pengembangan dan Model Pembelajaran Tematik Integratif. Jakarta: Prestasi Pustaka

Emzir. 2011. Metodologi Penelitian Pendidikan Kuantitatif dan Kualitatif. Jakarta : Rajawali Pers

Gauch, Hugh G. (2013). Scientific Method in Practice (Reprint ed.). Cambridge University Press. p. 3. ISBN 9780521017084.

Kemendikbud. 2013. Pedoman Kegiatan Pendampingan Implementasi Kurikulum 2013 oleh Pengawas Sekolah. Jakarta : Kemendikbud

Kunandar. 2008. Langkah Mudah Penelitian Tindakan Kelas Sebagai Pemgembangan Profesi Guru.Jakarta : Rineka Cipta

Kurniasih, Imas \& Berlin Sani. 2014. Sukses Menimplementasikan Kurikulum 2013. Surabaya: Kata Pena

Lazim. 2014. Penerapan Pendekatan Saintifik dalam Pembelajaran Kurikulum 2013. Yogyakarta

Hamalik, Oemar. Kurikulum dan Pembelajaran. Jakarta : PT. Bumi Aksara

Majid, Abdul. 2014. Pembelajaran Tematike Terpadu. Bandung: Rosdakarya

Mulyasa, E. 2010. Implementasi KTSP: Kemandirian Guru dan Kepala Sekolah. Jakarta: Bumi Aksara

Sanjaya, Wina. 2011. Strategi Pembelajaran Berorientasi Standar Proses Pendidikan. Jakarta: Kencana

Steven D. Schafersman. http://www.geo.sunysb.edu/esp/files/ scientificmethod.html (diakses 04 Agustus 2017)

Sugiyono. 2012. Metode Penelitian Pendidikan. Bandung: IKAPI

Varelas, $\mathrm{M}$ and Ford $\mathrm{M}$. The scientific method and scientific inquiry: Tensions in teaching and learning. (USA: Wiley Inter Science, 2009).

Wijaya, Kusumah dan Dedi dwitagama. 2011. Mengenal Penelitian Tindakan Kelas. Jakarta: PT. Indeks 